\title{
千葉県九十九里浜平野の完新統の発達過程
}

\author{
増田富士雄 ${ }^{* 1}$ ・藤原 治*2 - 酒井哲弥 ${ }^{* 1}$ ・荒谷 忠 ${ }^{* 1} \cdot$ \\ 田村 亨*1 鎌滝孝信 $* 2$
}

\begin{abstract}
浜堤平野を構成する地層の発達過程を捉える目的で, 千葉県九十九里浜平野において, 海岸線 之直交する方向での地質断面図が描けるように，深さ数 $\mathrm{m} \sim 24 \mathrm{~m}$ のボーリングを 19 本行った. 得られたコア試料に対する堆積相解析の結果, この地域の表層地下に分布する地層は, 鮮新一更 新統を基盤とし, 谷埋めエスチャリー泥層, 下部外浜基底の貝殻密集砂層, 下部外浜細粒砂層, 上部外浜細粒〜中粒砂層，海浜砂層，潟・氾濫原泥層からなることがわかった，コアから得られ た 73 試料の ${ }^{14} \mathrm{C}$ 年代值は，これらの地層が完新統からなることを示している．また，高密度の年 代值加ら作成した “堆積曲線”によって堆積年代が連続的に求まり，地質断面図上に 500 年ごと の等時間線を描くことができた．その結果，約 5,700 年前の縄文海進最高海面期以後に，海浜一 外浜システムが基盤にダウンラップしながら年 $1.4 \sim 1.6 \mathrm{~m}$ の速さで前進してこの完新統が形成 されたこと, 海岸線の前進速度が大きいと外浜勾配が急になること, 基底のダウンラップ型貝殼 密集砂層には海進期のラビーンメント堆積物が混入していることなどがわかった.
\end{abstract}

キーワード : ダウンラップ型貝殼密集層, 海浜一外浜堆積システム, 完新統，九十九里浜平野, 堆積曲線, ${ }^{14} \mathrm{C}$ 年代值

I. はじめに

千葉県の太平洋岸に長さ約 $60 \mathrm{~km}$ ，幅約 $10 \mathrm{~km}$ で広が る九十九里浜平野は, 浜堤列がよく発達した浜堤平野 (海浜平野 : strand plain)である.この平野は，地形と 表層地質の解析(森脇, 1979)加ら, 約 6,000 年前の縄文 海進の最高海面期以後, 現在までに海岸が海側に前進し て形成された平野であることがわかっている．地下の “沖積層”については, 数本の掘削デー夕(千葉県, 1997) や基底面高度図(関東地方土木地質図編纂委員会，1996） が公表されているにすぎない.

今回, 九十九里浜平野の中南部，埧黾川流域の海岸線 の延びに直交する地帯で, 16 本の深さ $2 \sim 8 \mathrm{~m}, 3$ 本の深 さ15〜24 $\mathrm{m}$ の掘削を行った，そして，それらのコアの 堆積相解析之, このコアで得られた 73 個の ${ }^{14} \mathrm{C}$ 年代測定 值の解析を行った．その結果，この地域の完新統サク セッションの発達過程を, 初めて明らかにすることがで きたので報告する.

\section{II. 調査地域と掘削地点}

九十九里浜平野の “沖積層” の発達様式が，海岸線と 直交した(陸一海)方向での地質断面として理解できるよ うな地点配置で地下掘削を行った.

掘削を行った地域は，千葉県九十九里浜平野の中南部 の真亀川流域である，掘削は，海岸線に直交した幅約 3 $\mathrm{km}$ の地帯の 19 地点(図 1)で, 採取径が $9.5 \mathrm{~cm}$ のボー リングおよび幅 $35 \mathrm{~cm}$ のジオスライサー(原口ほか, 1998)で行った. 3 地点(地点 04, 08, 14)では掘削深度 15 $\sim 24 \mathrm{~m}, 10$ 地点(地点 $02,06,07,09,11,12,13,15$, $16 ， 18)$ では掘削深度 $5 \sim 8 \mathrm{~m}$ のボーリング, および 6 地 点で深さ $1.5 \sim 3 \mathrm{~m}$ のジオスライサーで掘削試料を採取 した．地点の間隔は数 $100 \mathrm{~m} \sim 1 \mathrm{~km}$ である.

この地域は, 貝塚ほか(1979), 森脇(1979)によって地 形断面が示されているので, 解析結果と地形との対応が つきやすいという利点がある.ここでは，この海岸線に 直交した断面線(図 1 の A-B) に対して各掘削地点を投

2001 年 1 月 31 日受付. 2001 年 3 月 3 日受理. 2000 年度日本第四紀学会大会プレシンポジゥムにおいて講演.

*1 京都大学大学院理学研究科地質学鉱物学教室 干606-8502 京都市左京区北白川追分町. E-mail :

*2＼cjkstart核燃料サイクル開発機構東濃地科学センター厂509-5102 土岐市泉町定林寺 959-31. 


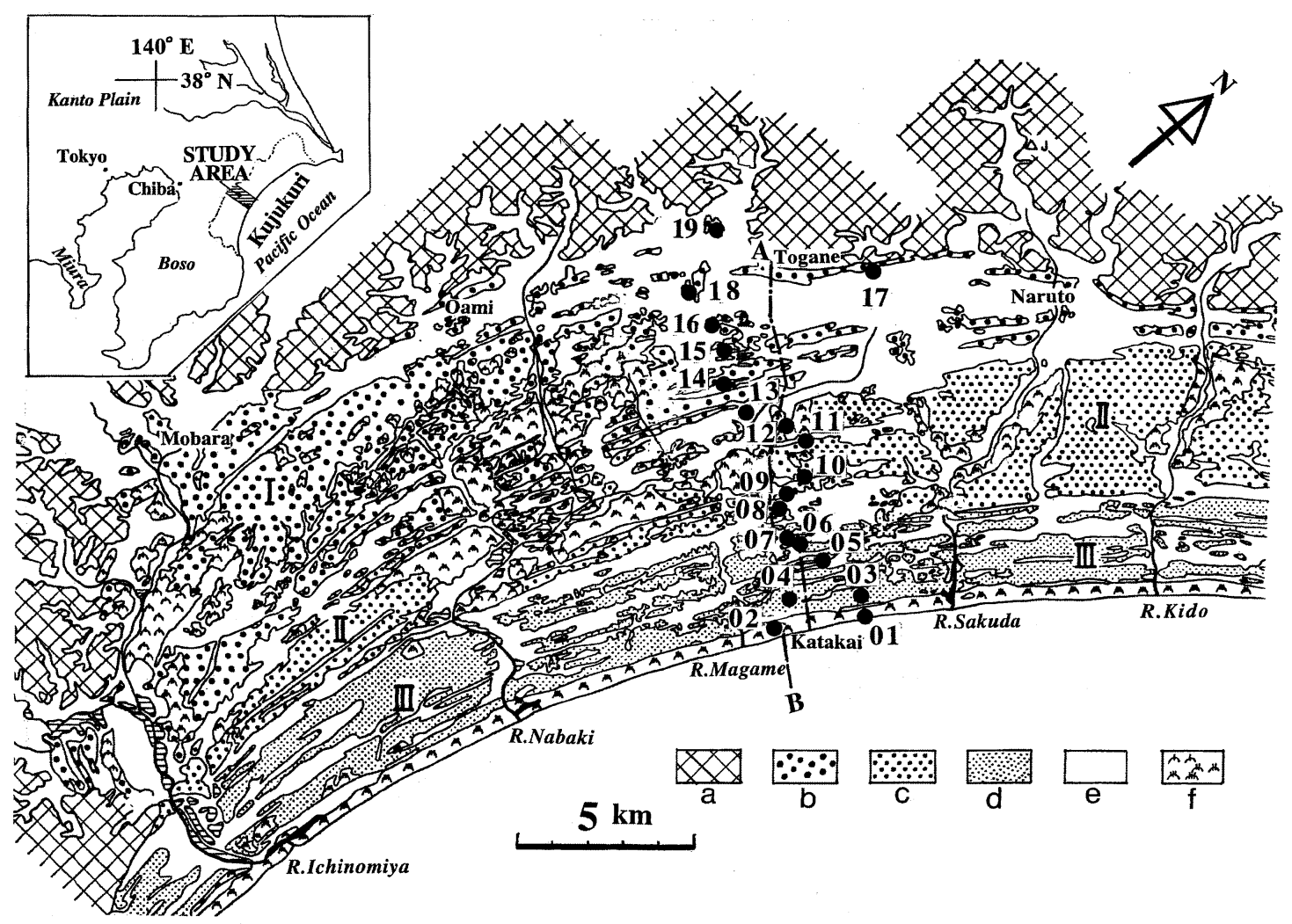

図 1 九十九里浜平野真亀川流域における掘削地点

黒丸 : 地点 $01 \sim 19$ A-B : 地形断面および地下地質断面の位置. a : 台地(基盤) b : 第 1 砂堤群( I ) $\quad \mathrm{c}$ : 第 2 砂堤 群 (II) $\mathrm{d}$ : 第 3 砂堤群(III) $\quad \mathrm{e}$ : 潟跡・砂堤間低地・氾濫原など $\mathrm{f}$ : 砂丘 地形区分図は森脇(1979)を使用.

影して柱状図をならべ，地下地質を理解する.

\section{III. 堆積相区分と堆積環境}

得られた堆積物について, 堆積相解析(増田, 1988, 1989, 1999 ; Walker and James, 1992)を行った. すなわ ち, 岩相, 堆積構造, 粒度, 基底面形状, 化石の観察办 ら, この地域の表層地質を 7 つ堆積相に区分した. ま た, その特徴から海浜から外浜, エスチャリーなどの堆 積環境を推定した. 貝化石種の生息域は波部(1977)など によった.

\section{1. 堆積相 $\mathrm{A}$ : 基盤層}

記載 固結度の高いシルト岩. 生痕化石や貝殼片を含 む. 地点 04 と地点 14 の最下部に, それぞれ厚さ $100 \mathrm{~cm}$ と $55 \mathrm{~cm}$ の厚さでみられる. 周辺台地の地質 (千葉県, 1997)との岩相の類似から, 上総層群に対比できる. これ はここで対象とする地層の基盤となる.

基盤上面の標高は, 地点 01 が- $17.5 \mathrm{~m}$, 地点 08 が
$-17.0 \mathrm{~m}$, 地点 14 が-8.3 mで, これまでの報告(関東 地方土木地質図編纂委員会, 1996)より15 30 m屯浅い.

\section{2. 堆積相 B : 谷埋めエスチャリー泥層}

記載 有機質のシルト層. 粘土磕や木片を含む. 上半 部には貝化石(Batilaria zonalis, Macoma incongrua, Cyclina sinensis, Anadara sp.: 潮間帯種や-20〜 - 30 $\mathrm{m}$ 以浅に生息する種)が, 下半部には根痕か認められる. 地点 08 の最下部(厚さ $330 \mathrm{~cm}$ ) にみられる.

堆積環境 地点 04 と地点 14 にはみられず分布が限 られること, 潮間帯や内湾性の貝化石種を含むこと, 下 位から上位に陸上から潮間帯さらに内湾と海進過程が読 み取れることから, 谷埋めの泥質エスチャリ一堆積物 (岡崎・増田, 1992) と考えられる.

3. 堆積相 C : 下部外浜基底の貝殻密集砂層

記載 貝化石の破片などを多く含む細粒〜中粒砂層 で, 貝殻密集層を構成する. 平行葉理力溌達した厚さ数 $\mathrm{cm} \sim 10 \mathrm{~cm}$ の砂層が重なり, この堆積相全体で上方細 
粒化を示す. 具化石は Umbonium giganteum, Babyronia japonica, Saxisodomus purpuratus, Mactra chinensis, Raetellops pulchella, Siliqua pulchella, Mactra crossei, Mactra nipponica, Cryptomya busoensis など, 潮下帯か らー20〜-100 $\mathrm{m}$ の細砂底から細砂泥底の種が多い. こ の堆積相は, 地点 04 , 地点 08 , 地点 14 の堆積相 A や堆 積相 B の直上に, 1 $1.5 \mathrm{~m}$ ほどの厚さでみられる. 下位 の堆積相 A や堆積相 B とは明瞭な境界面で接する. 特 に, 地点 08 や地点 14 では基底面か れた生痕がみられる。

堆積環境 明瞭な基底面をもち, 地点 08 でみられる ように含まれる貝化石群が下位より深くやや外洋性であ ることから，この堆積相は下部外浜でのダウンラップ型 あるいはオンラップ型の貝殻密集層(Kidwell, 1991 ; 近 藤，1998)にあたると考えられる. この貝殻密集砂層の成 因については，年代值を考慮に入れて後述する.

\section{4. 堆積相 D : 下部外浜細粒砂層}

記載 海棲貝化石を含む分級のよい細粒砂層で, 平行 葉理や低角くさび状葉理, ウェーブリップル葉理がみら れる. 厚さ数 $\mathrm{cm}$ 数 $10 \mathrm{~cm}$ の貝款密集層が挾まれる. 現地性と考えられる産状の貝化石はSiliqua pulchella, Mactra nipponica, Cryptomya busoensis, Nitidotellina hokkaidoensis など, 潮間帯からー20〜-80 m の細砂底 の生息種である.この堆積相の下部では生物擾乱が著し い. 地点 04 , 地点 08 , 地点 14 では中部から下部に厚さ 5〜8m で発達する. 下位の堆積相 C か ら漸移する.

堆積環境 波浪堆積構造のウェーブリップル葉理や八 ンモック状斜交層理(Harms et al., 1975)の一部と思わ れる低角くさび状葉理力認められること, それらがより 粗粒なストーム堆積物(Cheel and Leckie, 1993)として より細粒な砂層に挾まれること, 数 $10 \mathrm{~m}$ 以浅に生息す る貝化石種を含むことなどから, この堆積相は下部外 浜堆積物 (Brenchley, 1989 ; 斎藤, 1989 ; 岡崎・増田, 1992 ; Walker and Plint, 1992) と解釈される. 上部は癒 着したハンモック状斜交層理砂層の特徵を示し, 全体に は下部ほど細粒であり, 前進性の外浜砂層といえる.

\section{5. 堆積相 $\mathrm{E}:$ 上部外浜細粒〜中粒砂層}

記載 高角の斜交層理や低角くさび状葉理の発達した 細粒から中粒砂層である. 貝殼片か㵩理に沿って分布し たり, 厚さ数 $10 \mathrm{~cm}$ の上方細粒化層の基底に厚さ数 $\mathrm{cm}$ のラグとしてみられる. 堆積相 $\mathrm{E}$ は全体として上方に粗 粒化する. 現地性と考えられる貝化石は Mactra crossei, Meretrix lamarckii など, 潮下帯からー20 m に生息する 種である. 掘削深度の浅い地点を除いて多くの地点で認
められる. 堆積相の厚さは 4 6 m である.

堆積相 D とは, より粗粒なこと, 貝殼片を含む粗粒層 が多いこと，斜交層理がみられることなどから区別でき る.したがって堆積相 D との境界は明瞭である.

堆積環境 この堆積相は下位の堆積相 Dより粗粒で, 規模(セット高など)の大きい堆積構造がみられることか ら，より浅海域の堆積環境を示す．低角くさび状葉理は ハンモック状斜交層理の一部之考えられるので，この堆 積相は堆積相 D より粗粒な癒着したハンモック状斜交 層理砂層と大型の平板型やトラフ型の斜交層理を特徴と する上部外浜堆積物 (Brenchley, 1989 ; 斎藤, 1989 ; 岡 崎 - 増田, 1992 ; Walker and Plint, 1992) といえる.

\section{6. 堆積相 $\mathrm{F}:$ 海浜砂層}

記載 砂鉄質の平行葉理か溌達した分級のよい細粒砂 層. 逆級化構造や層厚の厚い薄いの繰り返しを示す厚さ 数 $\mathrm{cm}$ 以下の層や，特徵的な白斑状の生痕がみられる. 潮間帯棲の貝化石 Chion semigranosus を合弁で含む. また,この堆積相の上部には, 連続性の悪いやや不明瞭 な平行層理に小型の斜交葉理を挾む細粒〜中粒砂層や， 分級が非常によい細粒砂層がみられるところがある. この堆積相は, 厚さが 150 250 cm で, 多くの地点(地 点 13 と地点 19 を除くすべて)で認められた.

堆積環境 この堆積相の分級のよい砂鉄質平行葉理 は, 砂質海岸での前浜堆積物の特徵(Thompson, 1937 ; Reineck and Singh, 1980 ; 増田 • 岡崎, 1983 ; 増田 ・横 川, 1988)を示す. 水平で直線的な平行葉理は, 浅く速い 寄せ波・返し波で遡上帯に形成される流れの高領域での ベッドフォームであるプレーン・ベッド(平滑床)でつく られる. 低角のくさび状葉理は, 侵食面を挾んで堆積物 がオンラップ構造をとるときにつくられ(増田ほか, 1995), 厚さ数 $\mathrm{cm}$ 以下で逆級化構造を示す層は運搬時 に砂粒子同士が衝突して (Clifton, 1969 ; 増田ほか, 1995), 葉理の厚い薄いの繰り返しは日潮不等の潮位差 を反映して(Yokokawa and Masuda, 1991)形成された と考えられている. “ヒメスナホリムシの生痕”（菊地, 1972) とされてきた白斑状の生痕化石, Macaronichnus segregatis (Clifton and Thompson, 1978 ; 奈良, 1994) は, 砂質海岸の潮間帯(前浜)の指標(菊地, 1972 ; 増田 • 岡崎, 1983)である.

この堆積相の上部にみられる連続性の悪いやや不明瞭 な平行層理は, 後浜の堆積物で, そこにみられる小型斜 交葉理を挾む細粒砂層は後浜の小水路であるラネルの堆 積物で, 分級が非常によい細粒砂層は風成砂である(増 田・岡崎, 1983 ; 増田・横川, 1988). 
堆積相 $\mathrm{F}$ は海浜の前浜と後浜や砂丘の堆積物で, ここ では前浜堆積物を主体とする.

\section{7. 堆積相 G : 潟 - 氾濫原泥層}

記載 斜交葉理や平行葉理をもった細粒砂層を含むシ ルト層. 有機質の部分や根痕を含む泥層で生痕はみられ るが, 海成貝化石は含まれない. 現在の河川沿いの低地 （地点 13）では堆積相 $\mathrm{E}$ に侵食面をむって重なる. 厚さ は 1〜3 m. 現在の海岸から最屯陸側で, 台地に入り込ん だ谷部(地点 19)では, 厚さ $3 \mathrm{~m}$ 以上の泥層がみられ, そ の中部に上方細粒化を示す砂層力挾まれる. また, 最上 部には土袞や人工改变土などが一部にみられる.

堆積環境 海浜砂層(堆積相 F)の上位やそれらを削っ て堆積するこの泥層は, 海岸付近の潟や浜堤列間低地の 堆積物や河川の汇濫原堆積物 (岡崎 - 増田, 1992)で, 最 上部は表土である．潟堆積物と考えられる泥層に挾まれ る砂層は，津波堆積物(箕浦ほか, 1987 ; Takashimizu and Masuda, 2000)やストーム時の暴浪によるワッシュ オーバー堆積物(Barwis and Hayes, 1985 ; Murakoshi and Masuda, 1991)などと考えられる.

\section{IV. 地層の堆積年代}

堆積相解析を行った地層に対して得られた高密度な ${ }^{14} \mathrm{C}$ 年代測定值の結果から，500 年ごとの等時間線を地 質断面に入れる.

\section{1. ${ }^{14} \mathrm{C}$ 年 代 測 定}

地層の堆積年代を決めるため, 19 地点の不攪乱のコア (総コア長 $134.5 \mathrm{~m}$ )から 73 個の ${ }^{14} \mathrm{C}$ 年代測定值を求めた （表 1). 年代測定には，“現地性と考えられる”あるいは “保存状態が良い”殼をむった貝やウニなどの軟体動物 化石と, 潟堆積物中の植物片や木片を用いた. “現地性と 考えられる”化石試料とは，地層中で生息姿勢を保って 産出するむのである. “保存状態が良い殼”之は, 殼の細 かい装飾や模様がよく残っているあのや, 薄い殼が壊れ ていないものなどである(藤原ほか，2000).

${ }^{14} \mathrm{C}$ 年代は加速器質量分析法 (AMS) で求められた. 測 定值の暦年補正は Stuiver et al. (1998)の CALIB 4.0 の 方法 B を用いた. 植物化石試料ではデータセット 1 を, 軟体動物化石試料ではデータセット 3 を使用した. 後者 の場合, 海水のリザーバー効果は 400 年として求めた.

この論文では特に断りのない年代值はすべて 1950 年か らの暦年代值(年前)で表記する.

\section{2. 堆積年代の決定}

地層の堆積年代は堆積曲線から求める方法(増田, 1998，2000）を用いた. すなわち, 地点 04 , 地点 08 , 地
表 1 九十九里浜平野の掘削試料から得られた ${ }^{14} \mathrm{C}$ 年代值

\begin{tabular}{|c|c|c|c|c|}
\hline 試料No. & 採取標高 $(m)$ & 試料の種類 & ${ }^{14} \mathrm{C}$ 年代 (yr B.P.) & 暦年代 $(1 \sigma, y r$ B.P.) \\
\hline $02-1$ & $-0.1 \sim-0.2$ & 貝 & $748 \pm 44$ & $\begin{array}{c}433-336 \\
\end{array}$ \\
\hline $02-2$ & $-1.0 \sim-1.1$ & 貝 & $625 \pm 51$ & $324-223$ \\
\hline $02-3$ & $-2.4 \sim-2.5$ & 貝 & $651 \pm 49$ & $349-255$ \\
\hline $04-1$ & $-0.5 \sim-0.6$ & 頁 & $1170 \pm 60$ & $758-658$ \\
\hline $04-2$ & $-2.7 \sim-2.8$ & 貝 & $1280 \pm 45$ & $880-779$ \\
\hline $04-3$ & $-3.8 \sim-3.9$ & 貝 & $1420 \pm 50$ & $1005-917$ \\
\hline $04-4$ & $-4.7 \sim-4.8$ & 貝 & $1355 \pm 60$ & $953-833$ \\
\hline $04-5$ & $-6.0 \sim-6.1$ & 頁 & $1410 \pm 50$ & 999-908 \\
\hline $04-6$ & $-6.7 \sim-6.8$ & 貝 & $1585 \pm 60$ & $1204-1074$ \\
\hline $04-7$ & $-6.8 \sim-6.9$ & 頁 & $1840 \pm 65$ & $1442-1307$ \\
\hline $04-8$ & $-7.8 \sim-7.9$ & 貝 & $1865 \pm 50$ & $1462-1346$ \\
\hline $04-9$ & $-10.2 \sim-10.3$ & 貝 & $2030 \pm 65$ & $1673-1525$ \\
\hline $04-10$ & $-11.1 \sim-11.2$ & 貝 & $2060 \pm 65$ & $1697-1548$ \\
\hline $04-11$ & $-12.2 \sim-12.3$ & 貝 & $2250 \pm 45$ & $1904-1805$ \\
\hline $04-12$ & $-12.6 \sim-12.7$ & 貝 & $2105 \pm 50$ & $1737-1610$ \\
\hline $04-13$ & $-13.1 \sim-13.2$ & 貝 & $2305 \pm 45$ & $1963-1864$ \\
\hline $04-14$ & $-13.4 \sim-13.5$ & 貝 & $2440 \pm 120$ & $2215-1938$ \\
\hline $04-15$ & $-14.9 \sim-15.0$ & 貝 & $2660 \pm 40$ & $2369-2299$ \\
\hline $04-16$ & $-15.7 \sim-15.8$ & 貝 & $3020 \pm 45$ & $2816-2744$ \\
\hline $04-17$ & $-16.1 \sim-16.2$ & 貝 & $2770 \pm 45$ & $2577-2392$ \\
\hline $04-18$ & $-17.3 \sim-17.4$ & 貝 & $3895 \pm 50$ & $3933-3802$ \\
\hline $05-1$ & $0.3 \sim 0.4$ & 筫 & $1601 \pm 37$ & $1210-1126$ \\
\hline $06-1$ & $-1.4 \sim-1.5$ & 貝 & $1985 \pm 34$ & $1576-1505$ \\
\hline $07-1$ & $1.0 \sim 1.1$ & 木片 & $342 \pm 49$ & $398-319$ \\
\hline $07-2$ & $-1.7 \sim-1.8$ & 貝 & $2103 \pm 34$ & $1713-1627$ \\
\hline $08-1$ & $-0.9 \sim-1.0$ & 貝 & $2585 \pm 50$ & $2313-2201$ \\
\hline $08-2$ & $-2.2 \sim-2.3$ & 貝 & $2635 \pm 60$ & $2368-2218$ \\
\hline $08-3$ & $-3.4 \sim-3.5$ & 貝 & $2610 \pm 50$ & $2336-2238$ \\
\hline $08-4$ & $-3.8 \sim-3.9$ & 貝 & $2685 \pm 60$ & $2452-2308$ \\
\hline $08-5$ & $-5.1 \sim-5.2$ & 貝 & $2640 \pm 60$ & $2401-2242$ \\
\hline $08-6$ & $-5.9 \sim-6.0$ & 頁 & $2890 \pm 50$ & $2733-2611$ \\
\hline $08-7$ & $-6.6 \sim-6.7$ & 貝 & $3000 \pm 50$ & $2805-2728$ \\
\hline $08-8$ & $-7.5 \sim-7.6$ & 貝 & $3120 \pm 50$ & $2950-2824$ \\
\hline $08-9$ & $-8.6 \sim-8.7$ & ウニ & $3185 \pm 50$ & $3050-2909$ \\
\hline $08-10$ & $-9.6 \sim-9.7$ & 貝 & $3065 \pm 50$ & $2867-2767$ \\
\hline $08-11$ & $-10.5 \sim-10.6$ & 貝 & $3160 \pm 50$ & $3002-2865$ \\
\hline $08-12$ & $-11.3 \sim-11.4$ & ウニ & $3365 \pm 55$ & $3304-3166$ \\
\hline $08-13$ & $-12.7 \sim-12.8$ & 貝 & $3445 \pm 50$ & $3369-3262$ \\
\hline $08-14$ & $-13.5 \sim-13.6$ & 貝 & $3445 \pm 50$ & $3369-3263$ \\
\hline $08-15$ & $-14.8 \sim-14.9$ & 貝 & $3520 \pm 50$ & $3450-3350$ \\
\hline $08-16$ & $-15.7 \sim-15.8$ & 貝 & $3855 \pm 55$ & $3870-3724$ \\
\hline $08-17$ & $-16.3 \sim-16.4$ & 貝 & $4145 \pm 50$ & $4276-4136$ \\
\hline $08-18$ & $-16.7 \sim-16.8$ & 貝 & $4170 \pm 55$ & $4318-4156$ \\
\hline $08-19$ & $-17.7 \sim-17.8$ & 貝 & $8805 \pm 65$ & $9251-9071$ \\
\hline $08-20$ & $-18.1 \sim-18.2$ & 貝 & $8840 \pm 65$ & $9492-9295$ \\
\hline 09-1 & $-3.3 \sim-3.4$ & 貝 & $2858 \pm 38$ & $2705-2581$ \\
\hline $10-1$ & $0.7 \sim 0.8$ & 貝 & $2926 \pm 33$ & $2733-2702$ \\
\hline $10-2$ & $0.7 \sim 0.9$ & 貝 & $2830 \pm 33$ & $2673-2544$ \\
\hline $11-1$ & $3.1 \sim 3.2$ & 植物片 & $1717 \pm 52$ & $1631-1561$ \\
\hline $11-2$ & $-0.1 \sim-0.2$ & 貝 & $3466 \pm 38$ & $3385-3305$ \\
\hline $11-3$ & $-1.0 \sim-1.1$ & 貝 & $3675 \pm 35$ & $3626-3540$ \\
\hline $13-1$ & $1.9 \sim 2.0$ & 植物片 & $1558 \pm 34$ & $1490-1416$ \\
\hline $13-2$ & $0.5 \sim 0.6$ & 木片 & $3210 \pm 37$ & $3459-3394$ \\
\hline $13-3$ & $-1.0 \sim-1.1$ & 貝 & $3954 \pm 37$ & $3980-3878$ \\
\hline $14-1$ & $3.3 \sim 3.4$ & 貝 & $4160 \pm 70$ & $4332-4137$ \\
\hline $14-2$ & $0.9 \sim 1.0$ & 貝 & $4245 \pm 55$ & $4409-4270$ \\
\hline $14-3$ & $0.0 \sim 0.1$ & 貝 & $4225 \pm 55$ & $4390-4251$ \\
\hline $14-4$ & $-1.0 \sim-1.1$ & 貝 & $4375 \pm 70$ & $4597-4414$ \\
\hline $14-5$ & $-2.6 \sim-2.7$ & 貝 & $4415 \pm 50$ & $4644-4491$ \\
\hline $14-6$ & $-3.5 \sim-3.6$ & 貝 & $4510 \pm 55$ & $4792-4642$ \\
\hline $14-7$ & $-4.4 \sim-4.5$ & 貝 & $4720 \pm 55$ & $5008-4861$ \\
\hline $14-8$ & $-5.0 \sim-5.1$ & 貝 & $4665 \pm 55$ & $4939-4827$ \\
\hline $14-9$ & $-5.9 \sim-6.0$ & 貝 & $4715 \pm 55$ & $4998-4855$ \\
\hline $14-10$ & $-6.8 \sim-6.9$ & 貝 & $4630 \pm 55$ & $4910-4798$ \\
\hline $14-11$ & $-8.2 \sim-8.3$ & 貝 & $5220 \pm 55$ & $5640-5532$ \\
\hline $15-1$ & $4.0 \sim 4.2$ & 根 & $1550 \pm 32$ & $1489-1431$ \\
\hline $15-2$ & $-1.1 \sim-1.2$ & 貝 & $4577 \pm 39$ & $4835-4772$ \\
\hline $16-1$ & $0.8 \sim 0.9$ & 具 & $4727 \pm 85$ & $3980-3881$ \\
\hline $18-1$ & $6.6 \sim 6.8$ & 根 & $1867 \pm 34$ & $1831-1769$ \\
\hline $18-2$ & $6.4 \sim 6.5$ & 根 & $1806 \pm 31$ & $1782-1703$ \\
\hline $18-3$ & $3.6 \sim 3.7$ & 貝 & $5344 \pm 38$ & $5732-5649$ \\
\hline $19-1$ & $8.1 \sim 8.2$ & 木片 & $2212 \pm 33$ & $2206-2154$ \\
\hline $19-2$ & $7.8 \sim 7.9$ & 木片 & $2439 \pm 37$ & $2488-2362$ \\
\hline
\end{tabular}

試料 No. のはじめの 2 桁数字は地点番号を示す. 暦 年代への変換法は本文参照.

点 14 の長いコアについて, そこで得られた ${ }^{14} \mathrm{C}$ 年代値と その試料を採取した高度(標高)を，標高一年代ダイアグ ラム上にプロットして, 各デー夕点を滑らかに結んだ曲 線, 堆積曲線をつくり, その曲線からら各層準の年代值を 決めた.この研究では, 採取試料の吟味之高密度での年 
代値の決定が行われているので，“滑らかな”曲線を描く ことができ(図 2), この曲線から過去 5,500 年間の 500 年ごとの堆積年代を十分な精度で決めることができた。

堆積曲線(図 2) は, 厚さ 10 15 m の下部外浜汃ら海 浜のサクセッション(堆積相 C, D, E, F)がわずか $1,350 \sim 2,000$ 年間で形成されたこと, 特に上部外浜砂層 (堆積相 $\mathrm{E}:$ 厚さ $4 \sim 6 \mathrm{~m}$ ) は 70 430 年という短い期間 で累積したことを示している.さらに上位の前浜堆積物 (厚さ $1.2 \sim 2.2 \mathrm{~m}$ )の形成期間は, 100 年以下と推定され
ている(増田ほか, 2001).これらの堆積曲線(図 2)は, 外 浜堆積物がどの程度の時間で累積したものかを具体的に 提示できた貴重な例といえる.

また，堆積曲線(図 2)には外浜砂層(堆積相 C, D, E) の中で年代が急変するところが認められる，それはみか けの堆積速度が低下するところであり，一定速度で堆積 した層が侵食により欠けた結果と考えられる. その急変 するところは粗粒層の基底に対応させることができる.

図 3 は地点 08 を例として, この堆積過程をモデル化し

AGE

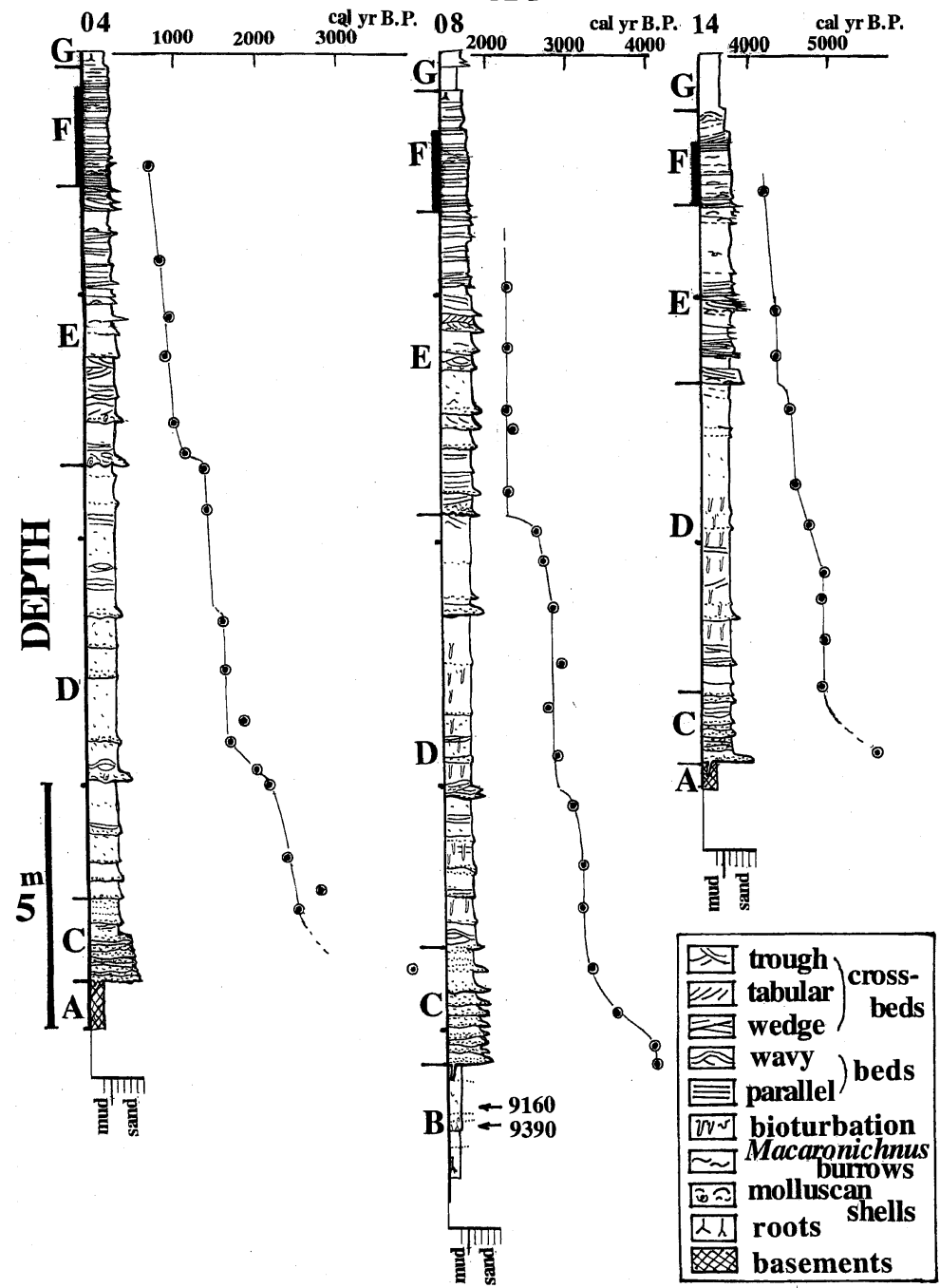

図 2 地点 04 , 地点 08 , 地点 14 における完新統の堆積相之堆積曲線 柱状図左の $\mathrm{A} \sim \mathrm{G}$ は堆積相. 堆積相 $\mathrm{F}$ 内の太線区間は前浜堆積物の層準. 柱状図右の数字 は年代值. 地点位置は図 1 に, 年代值は表 1 に示した。 
たあのである.

下部外浜砂層(堆積相 D) にみられる年代ギャップ(図 2) は 300 年以下で, おそろら大きなストーム時の暴浪や 津波などによって海底が侵食したことで形成されたもの と考えられる. また, 上部外浜砂層(堆積相 $\mathrm{E}$ )の基底の 年代ギャップは 350 年以下で, 現在の海底環境から推定 すると, 大きなストームに伴う外側沿岸砂州の移動に よって形成されたと思われる. 上部外浜砂層(堆積相 $\mathrm{E}$ ) 内での年代ギャップは 100 年以下で, 沿岸砂州の移動の 結果であろう.

\section{3. 過去の海岸線の位置}

海浜砂層(堆積相 $\mathrm{F}$ )の主体をなす前浜堆積物は, 潮間 帯で形成されたので, 各地点の前浜堆積物の年代が決ま れば, 過去の海岸線の位置がわかる. 増田ほか(2001)は 各地点の年代を, 前浜堆積物およびその直下の最上部外 浜堆積物に含まれる “保存状態が良い殼” ${ }^{14} \mathrm{C}$ 年代值 から推定した. 海浜堆積物から年代值が直接求められた 地点は 4 地点 (地点 $04,05,10,14$ ) で, それ以外の地点
については，同じコアから複数の年代值が得られている 4 地点(地点 $02,04,08,14$ )での堆積曲線で, 堆積速度 が最も速い地点 08 と遅い地点 04 を用いて, 年代值の最 小值と最大値とした.

こうして求めた各地点の海浜堆積物の年代と現在の海 岸線加の距離との関係(図 4)から, 過去約 5,700 年間 の 500 年ごとの海岸線の位置を決めた. 具体的な年代値 や距離などは，増田ほか(2001)に示されている。

\section{V. 地層の発達過程}

地質断面に等時間線を入れることは地層の発達様式を 理解するために重要である(増田, 1993)。ささらに, この 九十九里浜平野での例のように, 地質断面に ${ }^{14} \mathrm{C}$ 年代值 による等時間線が入ると, 形成時間や発達速度など地層 の発達過程をダイナミックに捉えることができる.

\section{1. 九十九里浜平野地下の完新統}

ここで得られた年代値(表 1)は，この地域の表層地下 の地層(いわゆる “沖積層”)がおる

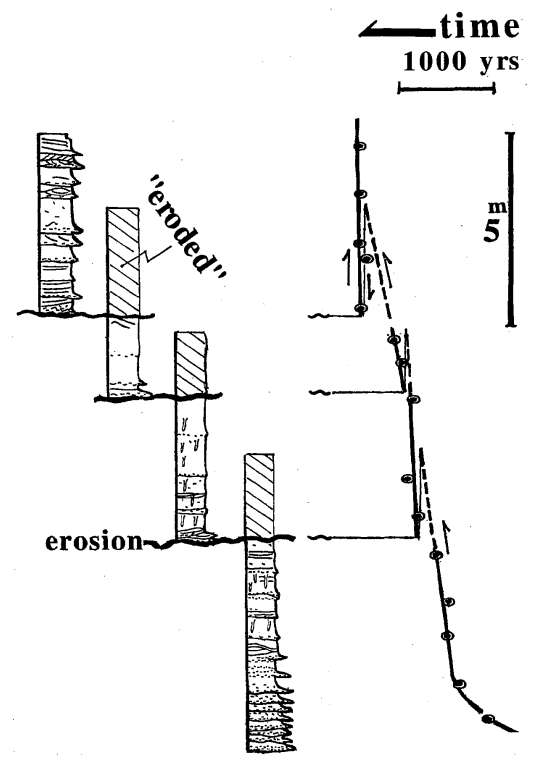

図 3 外浜堆積物 (堆積相 C, D, E) 中 の年代ギャップを侵食で説明する モデル図

堆積曲線は太線から破線そして細 線への変化を繰り返した結果をみ ている. 柱状図の斜線部分は堆積 後に侵食されてしまった部分. 地 点 08 を例としている. 柱状図の 凡例は図 3 に同じ.

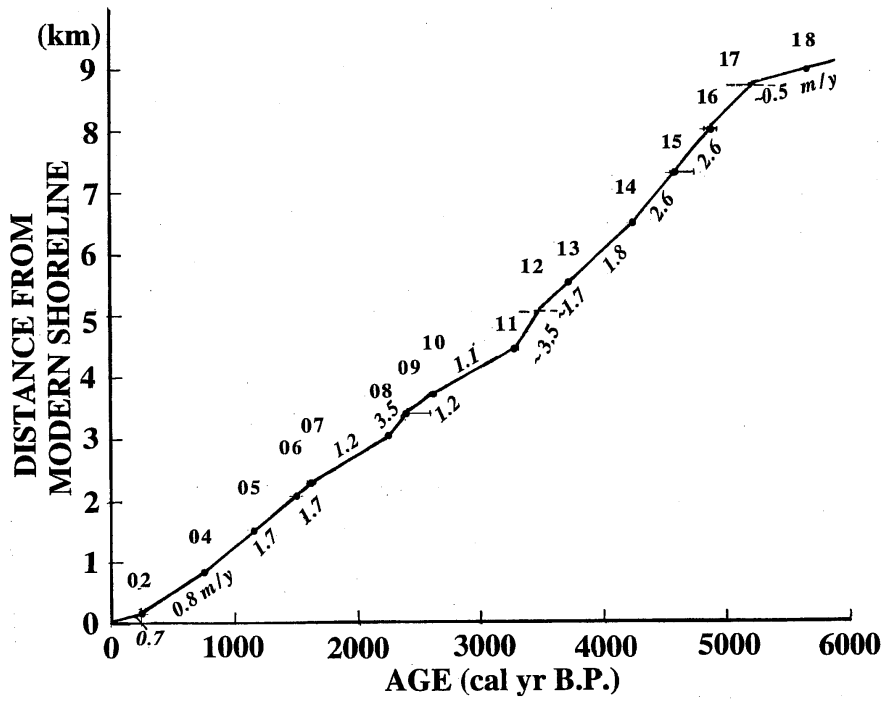

図 4 九十九里浜平野における過去 6,000 年間の海岸線の 前進速度の变化

過去の海岸線の位置を示す前浜堆積物が認められた 地点の現在の海岸線からの距離と, その前浜堆積物 の年代值との関係で示す. 数字 $01 \sim 18$ は地点番号. 斜体数字は隣り合う 2 地点を直線で結んだみかけの 前進速度 $(\mathrm{m} /$ 年). 
新統からなることを示している.

地質断面の下部では, 堆積相 A を基盤とし, 堆積相 B が局所的に分布する. 地点 08 では堆積相 $\mathrm{B}$ (谷埋めエス チャリー泥層) から約 9,160 年前(標高 $-17.85 \mathrm{~m}$ ) と 9,390 年前(標高 -18.15 m) の年代が得られている(図 2).これらの年代は後水期の海進時にあたり, 最終水期 の河谷が海進期に埋積されて堆積相 B となったことを 示している. その堆積物が海面付近のあのであり, 特に 後者の年代值が潮間帯種(Batillaria zonalis)から得られ たことから，それが現地性であることを前提とすれば， この地域では約 9,400 年前に相対的海水準は標高 -18 $\mathrm{m}$ 付近にあったことになる.

その上位に明瞭な侵食面をむって広く重なる外浜砂層 （堆積相 C, D, E)や海浜砂層(堆積相 F) の年代は, 陸側
に位置する地点 18 の上部外浜砂層 (堆積相 $\mathrm{E}$ ) で得られ た 5,690 年前, あるいは地点 14 の下部の貝款密集砂層 (堆積相 C) で得られた 5,590 年前という年代值より若い (図 2, 図 5, 表 1). すなわち, 九十九里浜平野の表層地 下の地層は, 約 6,000 年以後の縄文海進最高海面期以降 の堆積物から構成される完新統である.

これまでに九十九里浜平野で報告されている最む標高 の高い所にある海成層の年代は, 椿海の標高 $2.9 \mathrm{~m}$ で得 られた海成層最上部の 6,100 年前 $\left({ }^{14} \mathrm{C}\right.$ 年代值 : 辻・鈴 木, 1977)である. 補正を考えると, 今回掘削した最む陸 側の地点 18 に海岸線があった年代, つまり 5,700 年前 頃が最も海面が高かった時期にあたるといえる.

\section{2. 地質断面での等時間線}

3 地点(地点 $04,08,14$ )の深いボーリングコアでの堆

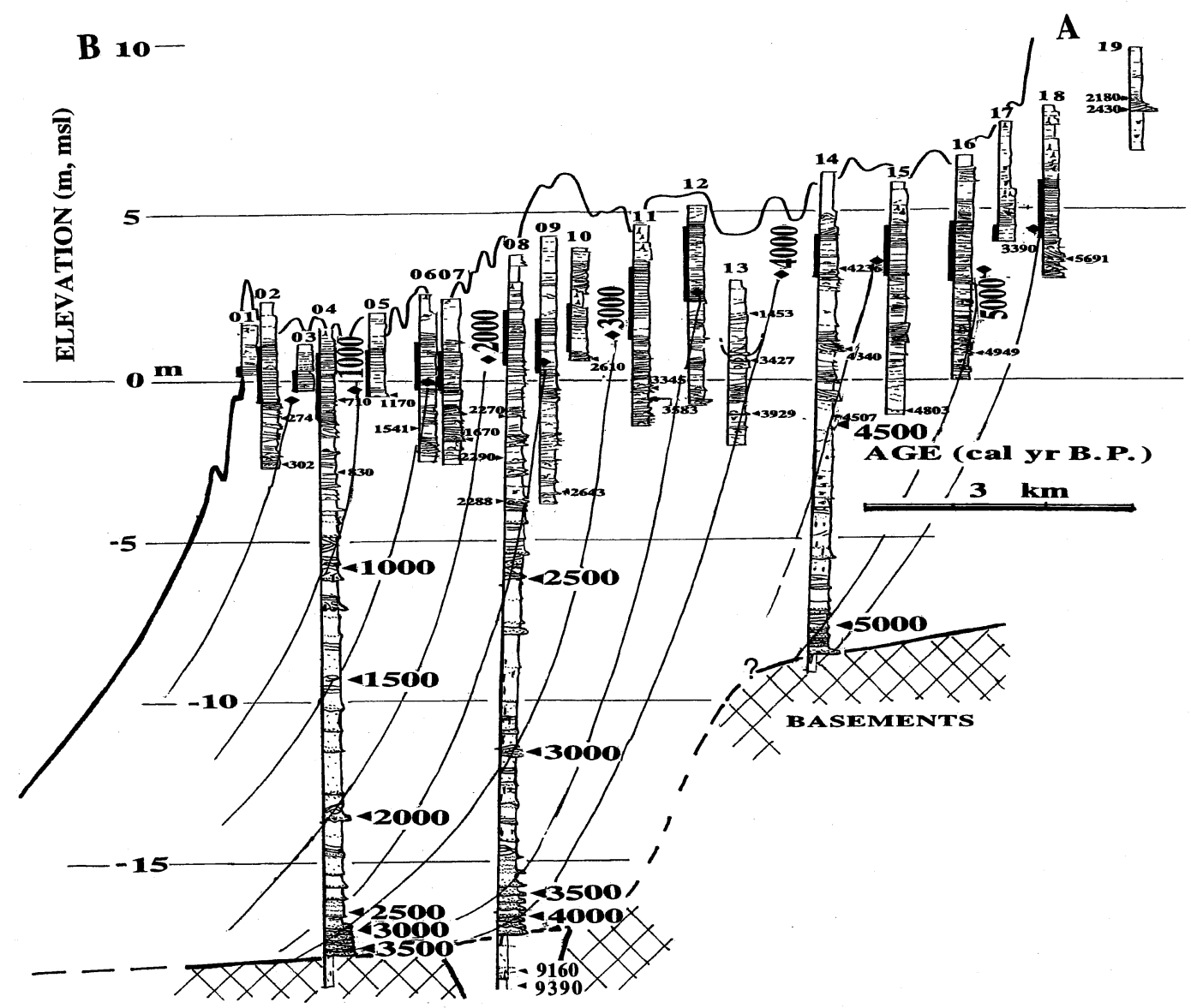

図 5 九十九里浜平野真龟川流域での海岸線に直交した方向での表層地下の地質断面 柱状図上の数字 $(01 \sim 19)$ は地点番号. 柱状図横の数字はおもな年代值 (表 1 の暦年代の中央値). 太字数字は堆積曲線か ら求めた 500 年ごとの堆積年代値. 曲線は 500 年ごとの等時間線. 地形断面は森脇(1979), 海底断面は国土地理院 (1977)による. 柱状図の凡例は図 2 に同じ. 
積年代と, 過去の海岸線の位置とから, 過去 6,000 年間 の 500 年ごとの等時間線を地質断面に描いた(図 5)、等 時間線は, 当時の海底地形の断面を示すと考えられるの で, 500 年ごとの海岸線の位置から現在の海底地形(図 5 の左側の地形断面 : 国土地理院, 1977)を参考に, 柱状図 の同じ堆積年代值の層準を通る曲線として描いた。

等時間線は過去の海底地形断面であるから下に凸の曲 線となり, 堆積(累積)速度は曲線の上部, すなわち地表 に近い部分ほど大きくなるということがわかる，九十九 里浜平野のように海側に前進して形成された堆積体の前 面の地形勾配は, そこでの堆積速度(累重速度), すなわ ち急斜面では速く, 緩斜面では遅いということを反映す る(増田・斎藤, 1995$)$.

描いた等時間線は， 5,500 年前と 5,000 年前，また $1,500 \sim 500$ 年前か涀在の海底断面線に近い形となるが, $4,500 \sim 2,000$ 年前, 特に $4,000 \sim 2,500$ 年前はそれより 急勾配でないと, 滑らかにデー夕点を通るようには引け ない．このことに関しては，多くの等時間線ではデー夕 点が 2 点から 4 点であって引くので, 描く曲線の自由度 が大きいところが多く, 粗い議論となるが, 基盤深度と 海岸線のみかけけ前進速度 (図 4) と関連させて, 次のよ うな説明が可能となる。

外浜地形(等時間線)が緩傾斜であった地点 18〜14の 地下までは基盤が浅く, この時期(地点 17 まで)の海岸 線の前進速度は小さかった. また, 地点 01〜03 の場合は 基盤の深度は不明であるが, 調査地域の沖合約 $10 \mathrm{~km}$ の 水深約 $25 \mathrm{~m}$ 付近に基盤が露出する(海上保安庁, 1963) ことから, 基盤上面は地点 04 の基盤深度 $(-21 \mathrm{~m})$ から ほとんど水平でごく緩く海側に傾斜していると考えられ る.この時期 (現在の海岸線〜地点 04 まで)の海岸線の 前進速度は小さい，一方，外浜地形(等時間線)か急傾斜 であった地点 08〜16 の地下の基盤は, 陸側より深く(図 5 の地点 08,04 参照), 海岸線の前進速度は大きい.

外浜勾配は, 前面が急に深くなると, また海岸線の前 進速度が大きくなると，より急勾配になっている．前面 が急に深くなった所では，供給される堆積物の量が同 じならば，それまでの海底勾配より必ず急になることは 容易に理解できる．また，海岸線が急激に前進すると浅 い所での堆積が進み, 深い所への堆積物供給が相対的に 減り, 外浜全体の勾配がより急になる。一方, 海岸線が ゆっくりと前進すると, 外浜下部への堆積物の供給が十 分に行われ，緩い安定した斜面形態になると考えられ る. 以上の説明が可能だとすると, 海岸線の前進速度と 外浜深度が大きい 4,500 年前あるいは 4,000 年前以後は
それ以前より堆積物の供給量が増えたことになる。

\section{3. ダウンラップ面}

等時間線が入った地質断面図(図 5) 之海岸線のみかけ の前進速度(図 4)汃ら, 九十九里浜平野の完新統は, 約 5,700 年前の縄文海進の最高海面期以後, 相対的海水準 が約 $5 \mathrm{~m}$ 低下する過程で, 海浜一外浜システムが年約 $0.5 \sim 3.5 \mathrm{~m}$ (平均 $1.4 \sim 1.6 \mathrm{~m} /$ 年)の速さで約 $9 \mathrm{~km}$ 前進 して形成されたことがわかる. すなわち, 海浜や外浜の 堆積物の年代が 6,000 年前以後であることから, 海浜一 外浜システム全体が基盤にダウンラップしながら前進し ている(図 5).したがって, 基盤(堆積相 A)や谷埋め工 スチャリー泥層(堆積相 B) と上位の貝殼密集砂層(堆積 相 C)の境界面はダウンラップ面で, それはダウンラッ プ型化石密集層(Kidwell, 1991 ; 近藤, 1998) となる.

すでに述べたように，そのダウンラップ面では年代 ギャップがある. すなわち, 地点 08 では約 5,000 年の年 代ギャップがあり, 地点 04 と地点 14 ではそれぞれ約 3,900 年前と約 5,700 年前の地層が更新〜鮮新統の基盤 の上に直接重なるという大きな年代ギャップがある. 地 点 08 のダウンラップ面上の貝殼密集砂層に含まれる “保存状態の悪い殼” は, 堆積曲線から求められたこの層 準の年代之 500 年から 5,000 年屯古い年代値を示す(藤 原ほか, 2000). 基底部には 8,800 年前の海進期を示す貝 殼が，基底から $1 \mathrm{~m}$ 上位では $8,150 \sim 7,900$ 年前の海進 期, $6,100 \sim 6,300$ 年前の高海面期を示す “古い” 貝殼が 含まれる.これらの年代值は, この貝殼密集砂層(堆積相 C)が次のような堆積過程で形成されたことを示してい る.すなわち,この地点では 8,800 年前の海進期に外浜 侵食によって堆積したラビーンメント堆積物 (増田, 1993)に含まれていた貝殼やその後に暴浪や津波(?)な ぞで運びこまれた貝殻が, $4,250 \sim 3,400$ 年前に再び波浪 限界水深より浅くなったときの堆積物に混入して再堆積 し, 堆積相 D のダウンラップ型の貝殼密集層か形成され たといえる.この貝殻密集砂層の粒度特性は, ほ加の堆 積相と違って, $3 \phi$ と $2 \phi$ 前後にピークをあつ 2 峰性の 分布を示す(田村・増田，1999).このことは，この貝殼 密集砂層には起源の異なる粒子群が混在するという, 上 で述べた堆積過程を支持している.

\section{VI. おわりに}

ここでは千葉県九十九里浜平野中南部で, 地下表層に 分布する完新統の陸一海方向での地質断面に等時間面を 入れ，その発達過程を明らかにした ${ }^{14} \mathrm{C}$ 年代值を利用し て地質断面に等時間面を入れ, 地層の発達過程をとらえ 
る試みは, 松下 (1979)の石狩平野での研究以後, 松島 (1984), 斎藤 (1987), 遠藤ほか (1992), 海津 (1992), Saito(1995)，増田(1998), Saito et al. (2000)などがあ る. しかし，そのほとんどは三角州や内湾についてで, 沿岸平野については松島(1984)の相模川低地之, 斎藤 （1987）の仙台平野に対する例などが報告されているにす ぎない，したがって，ここで明らかにした九十九里浜平 野の完新統での例は, 海進・海退を堆積相から読み取る シークェンス層序学にとって, 浜堤平野の形成モデルの 基礎となる貴重な例となる，そこでは海岸や外浜の前進 過程での急激な累積と，それによって生じるダウンラッ プ面の形成がその顕著な特徴であることがわかる.

さらに，地層でシークェンス層序区分を行う際には， 最む海域が広がった時期 (最大海氾濫面形成期)を地層で 特定するという重要なことが，現実には難しいというこ とがわかる. 例えば，九十九里浜平野の完新統の地質柱 状図(図 2)にみられる上方細粒化(地点 04，08，14 の堆 積相 C から堆積相 D の中部へ) と上方粗粒化(上方浅海 化, 堆積相 D の中部から堆積相 $\mathrm{E}$ へ)の変化を，一般に は海進加海退(あるいは高海面期)への変化と読み取る からである. 約 6,000 年前が最あ海面が高く, 海域が広 がった時期であることがわかっていなかったならば，解 釈を間違える可能性が高い. 九十九里浜平野の完新統の 例でも,「岩相と累積速度と相対的海水準は, 互いに同じ 関係で変化せず, 堆積システムや堆積場や時期の違いに よって，それぞれ異なった反応をする」（Masuda and Saito, 1999 ; 増田, 2000)ことを示し, 浅海層のシークェ ンス層序区分の難しさを改めて突きつけている.

今後, いろいろな堆積システムについて, 今回の研究 のような具体例か報告されれば，堆積体や地層の発達様 式や発達過程の理解が大きく進むことになろう.

\section{引用 文 献}

Barwis, J.H. and Hayes, M.O. (1985) Antidunes on modern and ancient washover fans. J. Sediment. Petrol., 55, 907-916.

Brenchley, P.J. (1989) Storm sedimentation. Geology Today, 7/8, 133-137.

Cheel, R. J. and Leckie, D.A. (1993) Hummocky crossstratification. Sedim. Rev., 1, 103-122.

千葉県 (1997) 千葉県の自然誌. 本編 2, 千葉県の大地. $823 \mathrm{p}$, 千葉県.

Clifton, H.E. (1969) Beach lamination : nature and origin. Mar. Geol., 7, 553-559.
Clifton, H.E. and Thompson, J.K. (1978) Macaronichnus segregatis : a feeding structure of shallow marine polychaetes. J. Sediment. Petrol., 48, 12931302.

遠藤邦彦・印牧むとこ・中井信之・森 育子・藤沢みど り・是枝若奈・小杉正人（1992）中川低地之三郷の地 質. 三郷市史編纂委員会編「三郷市史」: 35-111, 三郷 市.

藤原 治 - 鎌滝孝信 - 増田富士雄 (2000) 前進型外浜堆 積物中の貝殼の起源 : 千葉県九十九里浜の完新統の ${ }^{14} \mathrm{C}$ 年代測定值. 月刊地球， $22 ， 202-205$.

波部忠重 (1977) 日本産軟体動物分類学. $372 \mathrm{p}$, 北隆館. 原口 強 - 中田 高・島崎邦彦 - 今泉俊文 - 小島圭二 · 石丸恒存 (1998) 未固結堆積物の定方位連続地層採取 方法の開発とその応用. 応用地質, 39, 306-314.

Harms, J.C., Southard, J.B., Spearing, D.R. and Walker, R.G. (1975) Depositional environments as interpreted from primary sedimentary structures and stratification sequences. $161 \mathrm{p}$, Soc. Econ. Paleon. Miner. Short Course, 2.

海上保安庁 (1963) 東京湾至犬吠埼. 海図 (20 万分の 1) no. 87.

貝塚爽平 ・阿久津 純・杉原重夫・森脇 広 (1979) 千 葉県の低地之海岸における完新世の地形変化. 第四紀 研究, 17, 189-205.

関東地方土木地質図編纂委員会（1996）関東地方土木地 質図 (20 万分の 1$)$.

Kidwell, S.M. (1991) Taphonomic feedback (live/dead interactions) in the genesis of bioclastic beds : keys to reconstructing sedimentary dynamics. Einsele, G., Ricken, W. and Seilacher, A. (eds.) Cycles and events in stratigraphy:268-282, Springer-Verlag, Berlin.

菊地隆男（1972）成田層産白斑状化石生痕とその古地理 学的意義. 地質学雑誌, 78, 137-144.

国土地理院（1977）九十九里浜東部、沿岸海域地形図 (2.5 万分の 1$)$.

近藤康生（1998）海進海退サイクルの古生態学と夕フォ ノミー. 化石, 64, 54-60.

増田富士雄（1988，1989）ダイナミック地層学一古東京 湾域の堆積相解析から一その 1 , その 2 . 応用地質, 29, 30, 312-321, 29-40.

増田富士雄（1993）シークェンス層序学: 我が国におけ る陸域地質への適用例. 石油技術協会誌，58，292-310. 
増田富士雄（1998） 高密度で測定された ${ }^{14} \mathrm{C}$ 年代測定値 による完新統のダイナミック地層学. 地学雑誌，107, 713-727.

増田富士雄（1999）ダイナミック地層学一堆積と累重の 過程を明らかにする新しい地層学. $72 \mathrm{p}$, 深田研ライ ブラリー, 17, 深田地質研究所.

増田富士雄（2000）堆積曲線汃ら求める堆積年代と累重 速度. 月刊地球, 22, 191-197.

増田富士雄・岡崎浩子（1983）筑波台地およびその周辺 台地の第四系中にみられる方向を示す構造. 筑波の環 境研究 (筑波大), 7, 99-110.

増田富士雄・横川美和（1988）地層の海浜堆積物から読 み取れるもの. 月刊地球， $10 ， 523-530$.

増田富士雄・斎藤文紀（1995）プログラデーションによ る地層の特徵とテクトニクス的説明. 月刊地球, 17 , 671-674.

増田富士雄 ・ 岡崎浩子 - 横川美和 - 村越直美 - 酒井 哲弥（1995）更新統の海浜堆積物に対する MINISEQUENCE STRATIGRAPHY，地質学論集，45, 101-109.

Masuda, F. and Saito, Y. (1999) Temporal variations in depositional rates within a Holocene sequence in Japan. Saito, Y., Ikehara, K. and Katayama, H. (eds.) Land-sea link in Asia: "Prof. Kenneth O. Emery Commemorative International Workshop" : 421-426, Proceedings of an international workshop on sediment transport and storage in coastal sea-ocean system, STA (JISTEC) and Geol. Surv. Japan.

増田富士雄 - 藤原 治 - 酒井哲弥 - 荒谷 忠 (2001) 房 総半島九十九里浜平野の海浜堆積物から求めた過去 6000 年間の相対的海水準变動之地震隆起. 地学雑誌, 110 (印刷中).

松島義章（1984）日本列島における後水期の浅海性貝類 群集一特に環境变遷に伴うその時間・空間的変遷. 神 奈川県立博物館研究報告 (自然科学), 15, 37-109.

松下勝秀 (1979) 石狩海岸平野における埋没地形々上部 更新〜完新統について. 第四紀研究，18，69-78.

箕浦幸治 - 中谷 周 - 佐藤 裕（1987）湖沼底質堆積物 中に記録された地震津波の痕跡一青森市浦村十三付近 の湖沼系の例. 地震, 第 2 輯, 40, 183-196.

Murakoshi, N. and Masuda, F. (1991) A depositional model for a flood-tidal delta and washover sands in the late Pleistocene Paleo-Tokyo Bay, Japan. Smith, D.G., Reinson, G.E., Zaitlin, A. and Rahmani,
R.A. (eds.) Clastic tidal sedimentology : 219-226, Canadian Soc., Petrol. Geologists, Memoir 16.

森脇 広 (1979) 九十九里浜平野の地形発達史. 第四紀 研究, 18, 1-16.

奈良正和 (1994) “ヒメスナホリムシの生痕化石” の形成 者は何か? 一生痕化石 Macaronichnus segregatis の 形成メカニズム. 化石, 56, 9-20.

岡崎浩子・増田富士雄（1992）古東京湾地域の堆積シス テム. 地質学雑誌，98，235-258.

Reineck, H. E. and Singh, I. B. (1980) Depositional sedimenary environments. $549 \mathrm{p}$, Springer-Verlag, Berlin.

斎藤文紀（1987）海水準変動に支配された海成沖積層の 形成モデル. 月刊地球，9，533-541.

斎藤文紀（1989）陸棚堆積物の区分と暴風型陸棚におけ る堆積相. 地学雑誌, 98, 164-179.

Saito, Y. (1995) High-resolution sequence stratigraphy of an incised-valley fill in a wave- and fluvialdominated setting: Latest Pleistocene-Holocene examples from the Kanto Plain of central Japan. Mem. Geol. Soc. Japan, 45, 76-100.

Saito, Y., Wei, H., Zhou, Y., Nishimura, A., Sato, Y. and Yokota, S. (2000) Delta progradation and chenier formation in the Huanghe (Yellow River) delta, China. Jour. Asian Earth Sci., 18, 489-497.

Stuiver, M., Reimer, P.J., Bard, E., Beck, J.W., Burr, G. S., Hughen, K.A., Kromer, B., McCormac, F.G., Plicht, J. and Spurk, M. (1998) INTCAL 98 radiocarbon age calibration $24,000-0$ cal.BP. Radiocarbon, 40, 1041-1083.

Takashimizu, Y. and Masuda, F. (2000) Depositional facies and sedimentary successions of earthquakeinduced tsunami deposits in Upper Pleistocene incised valley fills, central Japan. Sed. Geol., 135, 231239.

田村 亨・増田富士雄（1999）海退期に形成された上方 細粒化汃ら粗粒化を示す海浜一外浜サクセション: 九 十九里平野の完新統. 日本地質学会第 106 年学術大会 講演要旨, 289.

Thompson, W.O. (1937) Original structures of beaches, bars, and dunes. Bull. Geol. Soc. Amer., 48, 723752.

辻 誠一郎・鈴木 茂 (1977) 九十九里平野北部の沖積 世干潟層の花粉分析的研究. 第四紀研究，16，1-12. 
海津正倫（1992）木曾川デル夕における沖積層の堆積過

程. 堆積学研究会報, 36, 47-56.

Walker, R.G. and James, N.P. (1992) Facies models : Response to sea level change. $409 \mathrm{p}$, Geol. Assoc. Canada.

Walker, R.G. and Plint, A.G. (1992) Wave- and stormdominated shallow marine system. Walker, R.G. and James, N.P. (eds.) Facies models : 219-238, Geol. Assoc. Canada.

Yokokawa, M. and Masuda, F. (1991) Tidal influence on foreshore deposits, Pacific coast of Japan. Smith, D.G., Reinson, G.E., Zaitlin, A. and Rahmani, R.A. (eds.) Clastic tidal sedimentology : 315-320, Canadian Soc., Petrol. Geologists, Memoir 16.

\title{
Progradation of the Holocene Beach-shoreface System in the Kujukuri Strand Plain, Pacific Coast of the Boso Peninsula, Central Japan
}

\author{
Fujio Masuda*1, Osamu Fujiwara*2, Tetsuya Sakai*1, Tadashi Araya*1, \\ Toru Tamura*1 and Takanobu Kamataki*2
}

\begin{abstract}
Nineteen cores, including several up to 24 meters long, were collected perpendicular to the shoreline in the Kujukuri strand plain for the purpose of identifying the development processes of stratigraphic succession. The succession is seen to be composed of the PlioPleistocene basement, incised valley-fill (estuary) muds, basal shell beds, lower shoreface fine sands, upper shoreface fine-medium sands, beach sands, and lagoonal and flood plain muds, in ascending order, based on facies analysis of the 19 cores. ${ }^{14} \mathrm{C}$ ages were determined for 73 samples from the cores, and they show that all the deposits are Holocene. The depositional ages for each horizon are discernible
\end{abstract}

by applying the so-called "Depositional curve method", which is based on having a dense array of age determinations in the cores. Isochronous lines representing 500-year intervals over the past 6,000 years were drawn for the Holocene succession. These results indicate that the beach-shoreface depositional system prograded at a rate of 1.4 to $1.6 \mathrm{~m}$ per year after a maximum highstand stage 5,700 years ago. The boundary between the basements and the Holocene is a so-called "downlap surface", and the basal condensed shell beds are downlap beds which include transgressive ravinement deposits.

*1 Department of Geology and Mineralogy, Graduate School of Science, Kyoto University. Kitashirakawa Oiwake-cho, Sakyo-ku, Kyoto, 606-8502 Japan. E-mail :

*2 Tono Geoscience Center, Japan Nuclear Cycle Development Institute. 959-31 Jorinji, Izumi-cho Toki, 509-5102, Japan. 